\title{
Erratum to: A Novel Maturation Function for Clearance of the Cytochrome P450 3A Substrate Midazolam from Preterm Neonates to Adults
}

\author{
Ibrahim Ince - Saskia N. de Wildt • Chenguang Wang • Mariska Y. M. Peeters • \\ Jacobus Burggraaf - Evelyne Jacqz-Aigrain · John N. van den Anker • \\ Dick Tibboel · Meindert Danhof · Catherijne A. J. Knibbe
}

Published online: 17 May 2013

(C) Springer International Publishing Switzerland 2013

\section{Erratum to: Clin Pharmacokinet \\ DOI 10.1007/s40262-013-0050-0}

A Published-Ahead-of-Print version of this article was made available online on 20 March 2013. An error has subsequently been identified in that version of the article, and the following correction should be noted:

The online version of the original article can be found under doi:10.1007/s40262-013-0050-0.

I. Ince · S. N. de Wildt · C. Wang · D. Tibboel - C. A. J. Knibbe Department of Pediatric Surgery and Intensive Care, Erasmus MC Sophia Children's Hospital, Rotterdam, The Netherlands

I. Ince - C. Wang - M. Danhof - C. A. J. Knibbe

Department of Pharmacology, Leiden/Amsterdam Center For Drug Research, Leiden, The Netherlands

M. Y. M. Peeters · C. A. J. Knibbe ( $\square)$

Department of Clinical Pharmacy, St. Antonius Hospital,

P.O. Box 2500, 3430 EM Nieuwegein, The Netherlands

e-mail: c.knibbe@antoniusziekenhuis.nl

J. Burggraaf

Centre for Human Drug Research, Leiden University,

Leiden, The Netherlands

E. Jacqz-Aigrain

Department of Pediatric Pharmacology and Pharmacogenetics,

University Diderot, Sorbonne Press Paris Cité,

Hopital Robert Debré, Paris, France

J. N. van den Anker

Children's National Medical Center, George Washington

University School of Medicine and Health Sciences,

Washington DC, USA
Author names: The third author's first name was incorrectly spelt as Chengueng and should appear as Chenguang 